\title{
Cannabinoids and the human uterus during pregnancy
}

\author{
Michael C. Dennedy, MB, BSc, Ann M. Friel, PhD, BSc, Diarmaid D. Houlihan, MB, BSc, \\ Venita M. Broderick, MB, Terry Smith, PhD, BSc, John J. Morrison, MD*
}

\author{
Departments of Obstetrics and Gynecology, Clinical Sciences Institute, and the Department of Biomedical Engineering \\ Science, National University of Ireland, Galway, Ireland
}

Received for publication January 30, 2003; revised July 11, 2003; accepted July 23, 2003

\section{KEY WORDS \\ Cannabinoid \\ Preterm delivery \\ Myometrium \\ Parturition}

There has been a marked increase in marijuana (cannabis) use during pregnancy in the last 20 years. ${ }^{1-3}$ This

* Reprint requests: John J. Morrison, MD, Department of Obstetrics and Gynecology, Clinical Sciences Institute, National University of Ireland Galway, University College Hospital, Newcastle Road, Galway, Ireland.

E-mail: john.morrison@nuigalway.ie

\begin{abstract}
Objective: The aim of this study was to investigate the expression of cannabinoid receptors in human uterine smooth muscle during pregnancy and to evaluate the effects of endogenous and exogenous cannabinoids on myometrial contractility in vitro.

Study design: Human myometrial biopsy specimens were obtained at elective cesarean delivery and snap frozen or mounted for isometric recording under physiologic conditions. Cumulative doses of the endogenous cannabinoid anandamide or the exogenous cannabinoid $\Delta^{9}$ (indicates a double bond between carbons 9 and 10) tetrahydrocannabinol were added in the range $1 \mathrm{nmol} / \mathrm{L}$ to $100 \mu \mathrm{mol} / \mathrm{L}$. Selectivity of the cannabinoid receptor agonists was investigated with specific antagonists for the $\mathrm{CB}_{1}$ and the $\mathrm{CB}_{2}$ receptors. Reverse transcription-polymerase chain reaction with primers for the $\mathrm{CB}_{1}$ and $\mathrm{CB}_{2}$ receptors was performed on messenger RNA that was isolated from human pregnant myometrium.

Results: Both anandamide and $\Delta^{9}$-tetrahydrocannabinol exerted a direct relaxant effect on human pregnant myometrium in vitro, which was of equal potency for both compounds. This relaxant effect was antagonized by the specific $\mathrm{CB}_{1}$ receptor antagonist, SR 141716, but not by the specific $\mathrm{CB}_{2}$ receptor antagonist, $\mathrm{SR} 144528(\mathrm{n}=6$ specimens, $P<.01)$. Both the $\mathrm{CB}_{1}$ and $\mathrm{CB}_{2}$ receptors are expressed in human myometrium.

Conclusions: Both endogenous and exogenous cannabinoids exert a potent and direct relaxant effect on human pregnant myometrium, which is mediated through the $\mathrm{CB}_{1}$ receptor. This highlights a possible role for endogenous cannabinoids during human parturition and pregnancy. These results also support the view that the use of exogenous cannabinoids during pregnancy is not linked independently with preterm labor.
\end{abstract}

(C) 2004 Elsevier Inc. All rights reserved. increase has raised questions about its potential adverse effects for the mother and developing fetus. ${ }^{3-7}$ Specific problems (such as low fetal birth weight, preterm delivery, miscarriage, stillbirth, congenital malformation, and neonatal complications) have been associated with cannabis use during pregnancy, ${ }^{3-8}$ with evidence that frequent or regular use is more hazardous than occasional use. ${ }^{2}$ 
The principal biologically active component of marijuana, $\Delta^{9}$-tetrahydrocannabinol $\left(\Delta^{9}-\mathrm{THC}\right)$, is a member of the cannabinoid family, which is known to exert the effects by way of the cannabinoid receptor subtypes, $\mathrm{CB}_{1}$ and $\mathrm{CB}_{2}{ }^{8,9}$ In 1992, after the discovery of the cannabinoid receptors, it was reported that arachidonoyl ethanolamine, also known as anandamide, is an endogenous ligand for these receptors (ie, an endogenous cannabinoid or endocannabinoid). ${ }^{10}$ Since then much research has focused on the role and effects of cannabinoids in different tissue systems. ${ }^{11-13}$ Little is known about the direct effects of cannabinoids on human reproductive tissues. In rats, it has been shown that the administration of anandamide or $\Delta^{9}$-THC prolonged the duration of pregnancy and increased the frequency of stillbirths. ${ }^{14,15} \mathrm{It}$ was suggested that this prolongation of pregnancy in rats may be linked to a reduction in uterine prostaglandin synthesis. However, $\mathrm{CB}_{1}$ and $\mathrm{CB}_{2}$ receptors are coupled through $G_{i / o}$ proteins to other intracellular signaling pathways (such as adenylate cyclase, mitogen-activated protein kinase, and ion channels) ${ }^{16-18}$ and therefore may have the ability to modulate uterine contractility directly. The aims of this study were to investigate for expression of the $\mathrm{CB}_{1}$ and $\mathrm{CB}_{2}$ receptors in human uterine smooth muscle (myometrium) that was obtained during pregnancy, to evaluate the direct effects of the cannabinoids anandamide and $\Delta^{9}$-THC on human uterine contractility during pregnancy, and to determine whether the uterine effects of these cannabinoids were mediated by the stimulation of the $\mathrm{CB}_{1}$ or $\mathrm{CB}_{2}$ receptors.

\section{Methods}

\section{Tissue collection}

Biopsy specimens of human myometrial tissue during pregnancy were obtained at elective cesarean delivery (ie, women not in labor) performed at term (37-42 weeks of gestation, $\mathrm{n}=11$ women). The biopsy specimens were excised from the upper midline portion of the incision in the lower uterine segment. Ethical committee approval was obtained from the Research Ethics Committee at University College Hospital, Galway, and recruitment was by written informed consent. Immediately on collection, the tissue for organ bath studies was placed in Krebs-Henseleit physiologic salt solution of the following composition: potassium chloride $4.7 \mathrm{mmol} / \mathrm{L}$, sodium chloride $118 \mathrm{mmol} / \mathrm{L}$, magnesium sulfate 1.2 $\mathrm{mmol} / \mathrm{L}$, calcium chloride $1.2 \mathrm{mmol} / \mathrm{L}$, potassium phosphate $1.2 \mathrm{mmol} / \mathrm{L}$, sodium bicarbonate $25 \mathrm{mmol} / \mathrm{L}$, and glucose $11 \mathrm{mmol} / \mathrm{L}$ (Sigma-Aldrich, Dublin, Ireland). Tissue for the organ bath studies was stored at $4{ }^{\circ} \mathrm{C}$ and used within 12 hours of collection. Immediately on collection tissue for RNA extraction was rinsed in normal saline solution, snap frozen in liquid nitrogen, and stored at $-70^{\circ} \mathrm{C}$.

\section{Myometrial tissue bath experiments}

Longitudinal myometrial strips were dissected, measuring approximately $2 \times 2 \times 10 \mathrm{~mm}$, and mounted under $2 g$ of tension in organ tissue baths for isometric recording as previously described. ${ }^{19-21}$ Each tissue bath contained $20 \mathrm{~mL}$ of Krebs-Henseleit physiologic salt solution, which was maintained at $37^{\circ} \mathrm{C}, \mathrm{pH} 7.4$, and gassed continuously with a mixture of $95 \%$ oxygen/ $5 \%$ carbon dioxide. The strips were allowed to equilibrate for at least 1 hour before the addition of oxytocin as a uterotonic agent. The Krebs-Henseleit physiologic salt solution in the tissue baths was changed every 15 minutes during the equilibration period. After equilibration, contractions were stimulated by bath exposure of the strips to oxytocin $(0.5 \mathrm{nmol} / \mathrm{L})$ for a period of 30 minutes, until regular phasic contractions were achieved. Bath addition of either the selective $\mathrm{CB}_{1}$ antagonist $\mathrm{SR}$ $141716^{22}$ or the selective $\mathrm{CB}_{2}$ antagonist $\mathrm{SR} 144528^{23}$ or of the respective vehicle for each antagonist was then performed for a further 30-minute period. This was followed by the addition of the endocannabinoid anandamide or the exogenous cannabinoid $\Delta^{9}$-THC, in a cumulative manner, at bath concentrations in the range $1 \mathrm{nmol} / \mathrm{L}$ to $100 \mu \mathrm{mol} / \mathrm{L}$ (ie, $10^{-9}-10^{-4} \mathrm{~mol} / \mathrm{L}$ ) at 20 minute intervals. The cumulative increases in bath concentration of anandamide or $\Delta^{9}$-THC were achieved in a pattern of $1 \log$ molar increase every 20 minutes (ie, $1 \mathrm{nmol}, 10 \mathrm{nmol}, 100 \mathrm{nmol})$. Control experiments that tested for tachyphylaxis, with a single dose for a similar time period, revealed no difference between isolated exposure and cumulative exposure during this time.

The mechanical response of tissues was measured by the calculation of the integral of selected areas for 20minute periods with the PowerLab hardware unit (AD Instruments, Oxfordshire, UK) and Chart software (version 3.6; AD Instruments). The integrated tension for the 20-minute period before the addition of cannabinoid, either anandamide or $\Delta^{9}$-THC, was calculated, and this value served as a control because no significant spontaneous reduction in myometrial contractility was observed over the duration of the experiments in the control strips. The effects of anandamide and $\Delta^{9}$-THC, in the presence or absence of antagonist, were assessed by the integral that was calculated during the 20 -minute period after the addition of each drug concentration and given as a percentage of the integral that was obtained in the 20-minute period before any drug addition (ie, percentage contractility).

\section{RNA extraction and reverse transcription}

Total RNA was isolated with TRIzol reagent (Life Technologies, Grand Island, NY). ${ }^{24}$ RNA was then reverse transcribed into complementary DNA (cDNA) for use as a template for polymerase chain reaction (PCR). One microgram of RNA was DNAase I treated 
(Ambion Inc, Austin, Tex). The RNA samples were then denatured at $65^{\circ} \mathrm{C}$ for 10 minutes. Reverse transcription was performed at $42^{\circ} \mathrm{C}$ for 60 minutes in a reaction volume of $20 \mu \mathrm{L}$ that contained oligo dT primer (500 ng), Maloney murine leukemia virus, reverse transcription buffer $(50 \mathrm{mmol} / \mathrm{L}$ TRIS-hydrochloric acid, $\mathrm{pH} 8.3$, $75 \mathrm{mmol} / \mathrm{L}$ potassium chloride, $3 \mathrm{mmol} / \mathrm{L}$ magnesium chloride, $10 \mathrm{mmol} / \mathrm{L}$ dithiothreitol; Promega, Madison, Wis), diethylpyrocarbonate-treated water (BDH, Dorset, UK), deoxyribonucleotide triphosphates $(0.1 \mu \mathrm{mol} /$ $\mathrm{L}$; Promega), and $200 \mu$ Maloney murine leukemia virus reverse transcriptase (Promega). Reverse transcriptase activity was stopped when the samples were heated at $65^{\circ} \mathrm{C}$ for 10 minutes. Control RNA samples, in which no reverse transcription enzyme was added, were included to confirm that no genomic DNA contamination was present.

\section{PCR}

The $5 \mu \mathrm{L}$ of each $20-\mu \mathrm{L}$ reverse transcriptase reaction was then used in subsequent PCR reactions. PCR was performed in a final volume of $50 \mu \mathrm{L}$ that contained $1.5 \mathrm{mmol} / \mathrm{L}$ magnesium chloride, $20 \mathrm{mmol} / \mathrm{L}$ TRIShydrochloric acid, $50 \mathrm{mmol} / \mathrm{L}$ potassium chloride, $\mathrm{pH}$ 8.3 (Life Technologies), $1.25 \mu$ Taq DNA polymerase (Life Technologies), $40 \mu \mathrm{mol} / \mathrm{L}$ deoxyribonucleotide triphosphates (Promega), and $0.2 \mathrm{pmol}$ of each sense and antisense primer. cDNA amplification was carried out by an initial denaturation step of 5 minutes at $95^{\circ} \mathrm{C}$ followed by 40 cycles of denaturation at $94^{\circ} \mathrm{C}$ for $20 \mathrm{sec}-$ onds, annealing at $60^{\circ} \mathrm{C}$ for 45 seconds, and elongation at $72^{\circ} \mathrm{C}$ for 20 seconds. The $5 \mu \mathrm{L}$ of each PCR product was then separated by gel electrophoresis on a $1.2 \%$ agarose gel. Products were run alongside a 100-bp DNA mass ladder (Sigma-Aldrich, Dublin, Ireland) for sizing. Primers that were used were designed according to published DNA and messenger RNA (mRNA) sequences from GenBank (Los Alamos, NM; $\mathrm{CB}_{1}$ receptor accession code $\mathrm{U} 73304, \mathrm{CB}_{2}$ receptor accession code $\mathrm{X} 74328$ ).

\section{Drugs and solutions}

A stock solution of oxytocin ( $1 \mathrm{mmol} / \mathrm{L}$, Sigma-Aldrich) was made in ethanol. Anandamide and $\Delta^{9}$-THC were obtained from Sigma-Aldrich (St Louis, Mo). A stock solution $\left(10^{-2} \mathrm{~mol} / \mathrm{L}\right)$ of anandamide or $\Delta^{9}-\mathrm{THC}$ was prepared with ethanol. The series of dilutions were made with deionized water on the day of the experimentation and were maintained at room temperature for the duration of the experiment. Fresh Krebs-Henseleit physiologic salt solution was made daily. SR 141716 was donated by B. R Martin, PhD, Virginia Commonwealth University, and also by Sanofi Recherche, Montpellier France. The SR 144528 was donated by Sanofi Recherche. Stock solutions $\left(10^{-3} \mathrm{~mol} / \mathrm{L}\right)$ of all three compounds were made with deionized water. A license was obtained for the possession and importation of $\Delta^{9}$ THC under the "Misuse of Drugs Acts, 1977 and 1984" and the "Misuse of Drugs Regulations, 1988" as set down by the government of the Republic of Ireland.

\section{Statistical analysis}

With the calculated integrals of contractile activity at each bath, the concentration dose response curves were analyzed by fitting the logistic equation: $\mathrm{Y}=\mathrm{Y} \max \times$ $\mathrm{D}_{\mathrm{H}}^{\mathrm{n}} / \mathrm{EC}_{50}+\mathrm{D}_{\mathrm{H}}^{\mathrm{n}}$, where $\mathrm{Y}$ is the response (percentage contractility), Y max is the maximal relaxation achieved, $\mathrm{D}$ is the dose of agonist (anandamide or $\Delta^{9}$-THC), ${ }_{\mathrm{H}}^{\mathrm{n}}$ is the slope function, and $\mathrm{EC}_{50}$ is the agonist dose giving one-half the maximal response. Curve fitting was performed with the software package Prism (Graphpad Software, San Diego, Calif). For myometrial tissue, the concentration of agonist (ie, anandamide or $\Delta^{9}$ THC) that resulted in one half the maximal inhibitory effect (ie, the $\mathrm{EC}_{50}$ ) was measured and represented in pharmacologic terms as its appropriate $-\log _{10}$ value (ie, $-\log _{10} \mathrm{EC}_{50}$ ), which is also known as the $\mathrm{pD}_{2}$. For example, if the $\mathrm{EC}_{50}$ value were $1 \mu \mathrm{mol} / \mathrm{L}$ (ie, $10^{-6}$ $\mathrm{mol} / \mathrm{L}$ ), the $\mathrm{pD}_{2}$ would be 6.0. Comparisons of $\mathrm{pD}_{2}$ $\left(-\log \mathrm{EC}_{50}\right)$ and mean maximal inhibitory (MMI) response values were carried out with a two-way analysis of variance. Post hoc comparisons were made with the Newman-Keuls test. A probability value of $<.05$ was accepted as statistically significant. The statistical package GBSTAT (version 6.5; Dynamic Microsystems Inc, Silver Spring, Md) was used for statistical calculations.

\section{Results}

Myometrial biopsy specimens were obtained from 11 women who underwent cesarean delivery between 38 and 40 weeks of gestation (median gestation, 39 weeks). All cesarean deliveries were carried out electively for the following reasons: breech presentation, previous cesarean delivery, previous myomectomy, previous shoulder dystocia, placenta previa, and fetal intrauterine growth restriction. The mean maternal age at delivery was 34.7 years (range, 21-37 years). The median parity value of the women at the time of delivery was 1 (range, $0-3)$. All women had regional anesthesia for cesarean delivery.

Both anandamide and $\Delta^{9}$-THC exerted a significant concentration-dependent relaxant effect on human myometrial contractility in vitro. Recordings of oxytocininduced myometrial contractions and the effects of cumulatively increasing concentrations of anandamide and $\Delta^{9}$ THC are shown in Figures $1, A$, and 2, $A$, respectively. For anandamide, the $\mathrm{pD}_{2}$ value was $5.58 \pm 0.42$ ( $\mathrm{n}=6$ specimens), the MMI response value was 

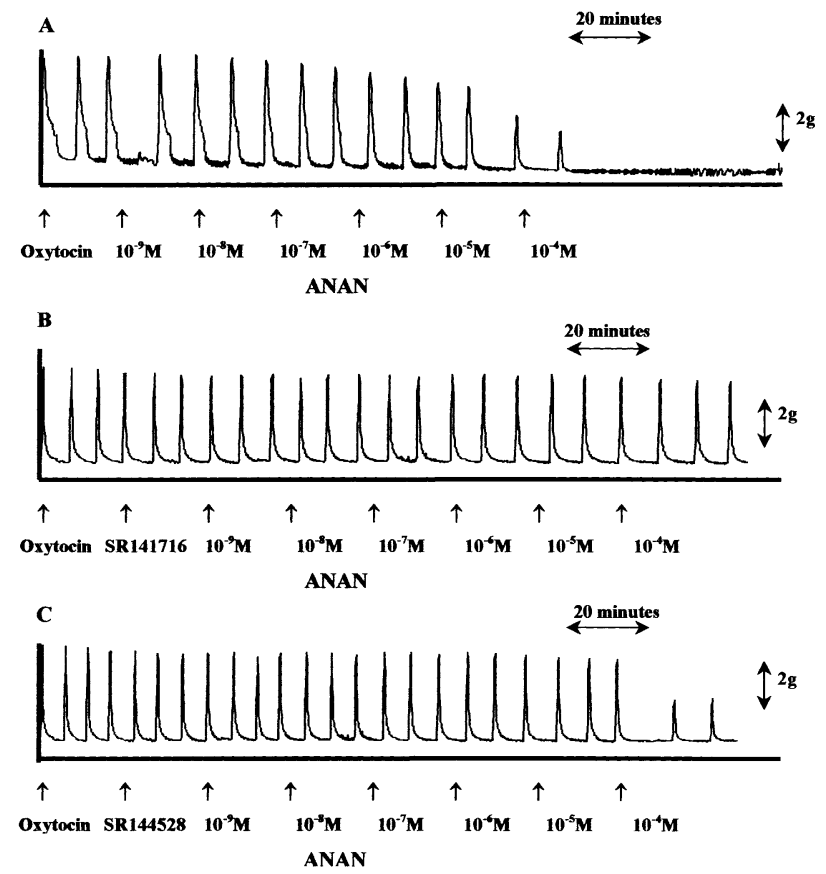

Figure 1 Representative recordings of oxytocin-induced contractions in human myometrial strips and the effects of anandamide are shown. A, The relaxant effect of anandamide $(A N A N)$ in myometrium is not preincubated with antagonist. B, Antagonism of the effects of anandamide in the presence of the $\mathrm{CB}_{1}$ antagonist SR 141716 is shown. C, No antagonism was observed with the $\mathrm{CB}_{2}$ antagonist SR 144528 .
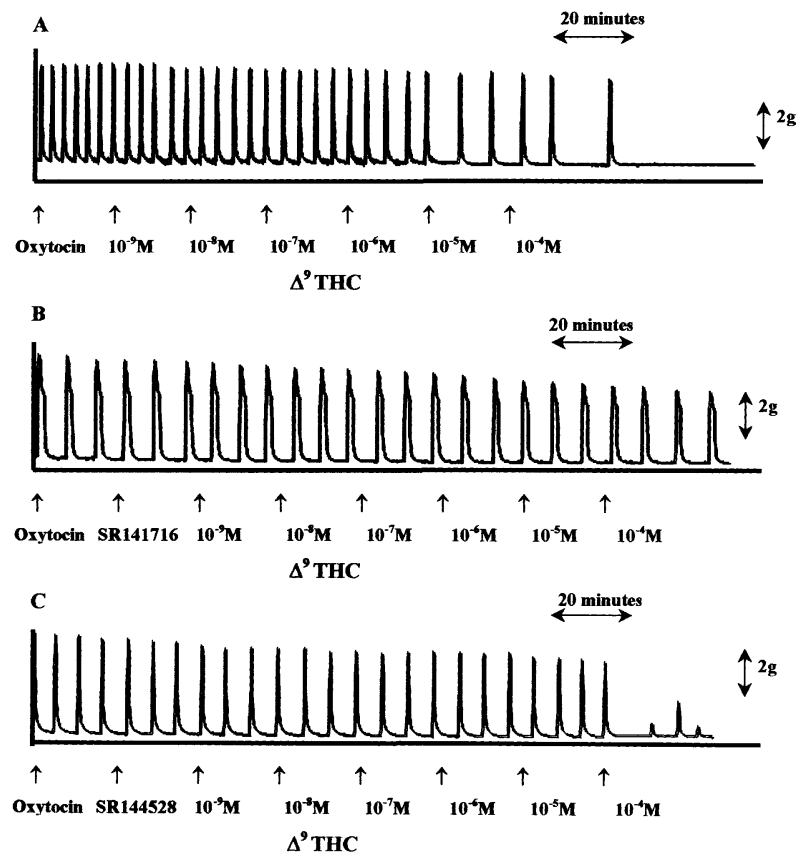

Figure 2 Representative recordings of oxytocin-induced contractions in human myometrial strips and the effects of $\Delta^{9}$-THC are shown. A, The relaxant effect of $\Delta^{9}$-THC in myometrium is not preincubated with antagonist. B, Antagonism of the effects of $\Delta^{9}$-THC in the presence of the $\mathrm{CB}_{1}$ antagonist SR 141716 is shown. C, No antagonism was observed with the $\mathrm{CB}_{2}$ antagonist SR 144528.

Table I Uterorelaxant effect of the cannabinoid agents in the absence and presence of antagonist

\begin{tabular}{|c|c|c|c|c|c|c|}
\hline \multirow[b]{2}{*}{ Agonist } & \multicolumn{2}{|c|}{ No antagonist } & \multicolumn{2}{|c|}{$+\mathrm{SR} 141716$ ( $\mathrm{CB}_{1}$ anatgonist $)$} & \multicolumn{2}{|c|}{ +SR 144528 ( $\mathrm{CB}_{2}$ antagonist) } \\
\hline & $\mathrm{pD}_{2}$ & MMI & $\mathrm{pD}_{2}$ & MMI & $\mathrm{pD}_{2}$ & MMI \\
\hline$\overline{\Delta^{9}-\mathrm{THC}}$ & $5.19 \pm 0.91$ & $75.05 \pm 1.15$ & $2.57 \pm 0.18^{*}$ & $34.44 \pm 2.28^{*}$ & $5.73 \pm 0.30$ & $74.07 \pm 3.72$ \\
\hline
\end{tabular}

$75.74 \% \pm 2.20 \%$ ( $\mathrm{n}=6$ specimens $)$, and the corresponding values for $\Delta^{9}$-THC were $5.20 \pm 0.94(\mathrm{n}=6$ specimens) and $75.04 \% \pm 1.15 \%(\mathrm{n}=6$ specimens, Table I). There was no significant difference between the potencies of both compounds.

The selective $\mathrm{CB}_{1}$ antagonist SR 141716 produced a parallel rightward shift of the dose response curve for both anandamide (Figure 3, $A$ ) and $\Delta^{9}$-THC (Figure $3, B)$, which indicated antagonism of their effects. Examples of raw data recordings of myometrial contractions in vitro that demonstrated antagonism by SR 141716 are shown in Figures $1, B$, and 2, $B$, for anandamide and $\Delta^{9}$-THC, respectively. There was a significant difference between the $\mathrm{pD}_{2}$ values for both anandamide and $\Delta^{9}$-THC in the absence and presence of SR141716 (n $=6$ specimens, $P<.01$, Table I). There was also a significant difference between the MMI response values for both anandamide and $\Delta^{9}$-THC in the absence and presence of SR141716 $(\mathrm{n}=6$ specimens, $P<.01$, Table I). On the contrary, the $\mathrm{CB}_{2}$ antagonist SR 144528 did not result in any significant alteration in the dose response curve for either anandamide or $\Delta^{9}$-THC, as demonstrated in Figures 1, $C$, and 2, $C$, respectively, and also in Figure 3, $A$ and $B$, respectively. There was no significant difference between the $\mathrm{pD}_{2}$ values or the MMI response values for either anandamide or $\Delta^{9}$-THC in the presence or absence of SR 144528 (Table I).

Reverse transcriptase reaction products were subjected to PCR amplification with oligonucleotide primer sets that corresponded to both cannabinoid receptor 
A

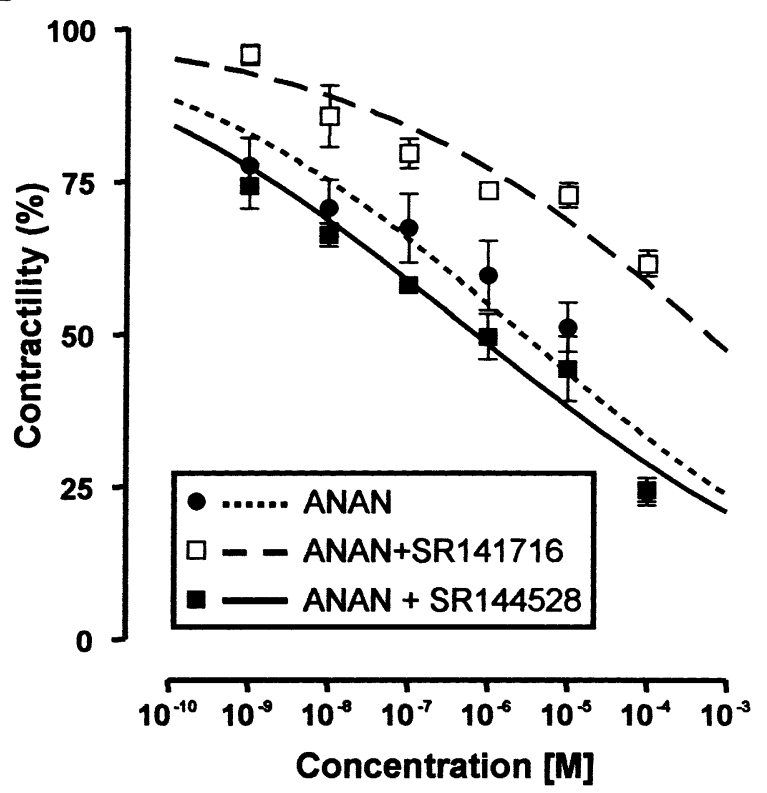

B

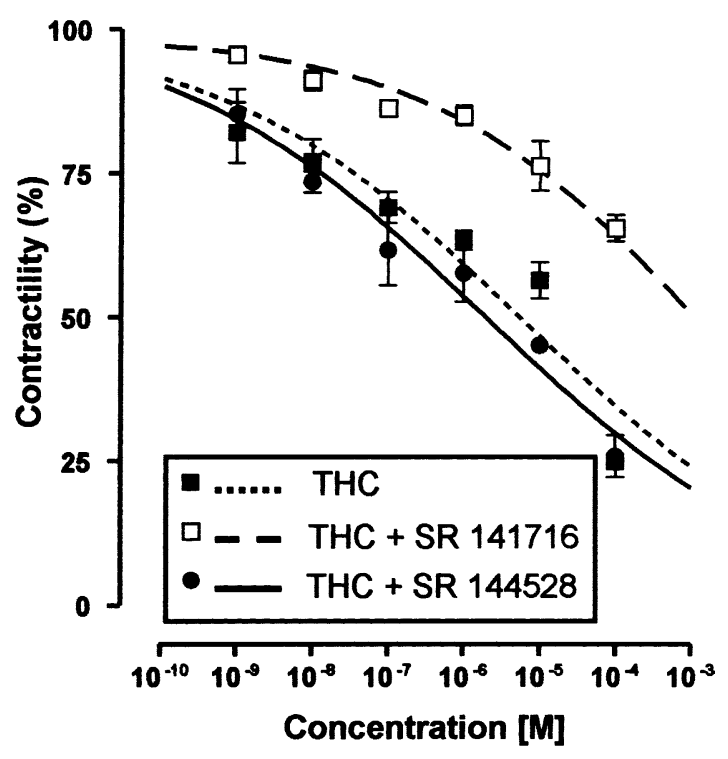

Figure $3 \mathbf{A}$, The dose response curves demonstrates the uterorelaxant effect of the endogenous cannabinoid, anandamide alone (closed circles) and with bath pre-exposure to the $\mathrm{CB}_{1}$ receptor antagonist SR 141716 (open squares) or the $\mathrm{CB}_{2}$ receptor antagonist SR 144528 (closed squares). B, The doseresponse curves demonstrate the uterorelaxant effect of the exogenous cannabinoid, $\Delta^{9}$-THC alone (closed squares) and with bath pre-exposure to SR 141716 (open squares) or SR 144528 (closed circles). Percentage contractility is shown on the $y$-axis, and the concentration of agonist is shown on the $x$-axis. The points represent the means, and the error bars represent the SEM.

subtypes. Both primer sets yielded PCR products of the expected sizes $(\mathrm{n}=2$ sets, Figure 4 and Table II). Amplification with the $\mathrm{CB}_{1}$ primer set resulted in a 345-bp PCR product. This product was sequenced (MWG-Bio- tech Ltd., Milton Keynes, UK), and the results verified that it was a part of the $\mathrm{CB}_{1}$ receptor gene. Amplification of myometrial cDNA with $\mathrm{CB}_{2}$ primers yielded a 439-bp product for which sequence analysis confirmed it to be part of the $\mathrm{CB}_{2}$ receptor gene sequence. PCR of the reverse transcriptase negative controls showed no amplification that confirmed no genomic DNA contamination. Similarly, the PCR negative control (no cDNA template) showed no amplification product.

\section{Comment}

This is the first demonstration of the presence of cannabinoid receptors in human uterine smooth muscle and the first report that outlines that the endogenous cannabinoid anandamide and the exogenous cannabinoid $\Delta^{9}$ THC exert a potent relaxant effect on oxytocin-induced human myometrial contractility. Endogenous cannabinoids have been the subject of much research interest in vascular ${ }^{11}$ and nonvascular ${ }^{12}$ smooth muscle systems in recent years. Little is known about the role of endogenous cannabinoids in human reproduction. In the mouse, it has been suggested that the aberrant synthesis of anandamide or the aberrant expression of cannabinoid receptors in the uterus or embryo may account for early pregnancy failure or female infertility. ${ }^{25}$ Similarly, low fatty acid amide hydrolase activity, the anandamide degrading enzyme, has been implicated as a cause of implantation failure and pregnancy loss in humans. ${ }^{26}$ In rats it has been demonstrated that the administration of endogenous (anandamide) or exogenous $\left(\Delta^{9}\right.$-THC) cannabinoids results in an increase in the duration of pregnancy and in the frequency of stillbirths. ${ }^{15}$ It was suggested that this may be due to the central effects of the cannabinoids. Our findings demonstrate a clear direct effect of endogenous and exogenous cannabinoids on myometrial function and raise questions about a possible role of endogenous cannabinoids in the maintenance of uterine quiescence during normal pregnancy.

We have shown that the relaxant effect of the endogenous and exogenous cannabinoids in human uterine smooth muscle appears to be mediated predominantly through the $\mathrm{CB}_{1}$ receptor. Previously $\mathrm{CB}_{1}$ mRNA has been detected in the central nervous system and in peripheral tissues that include heart, lung, bladder, and adrenal gland. ${ }^{16,27}$ In vascular tissues, the vasodilatation and hypotension that is elicited by endocannabinoids appear to be also mediated through the $\mathrm{CB}_{1}$ receptor. ${ }^{11,28}$ In the gastrointestinal system, the activation of $\mathrm{CB}_{1}$ receptors inhibits gastrointestinal motility, intestinal secretion, and gastric acid secretion. ${ }^{27}$ The proposed signal transduction pathways that are linked to cannabinoid receptor agonists include the inhibition of N-type and P/Q-type voltage sensitive calcium 
A

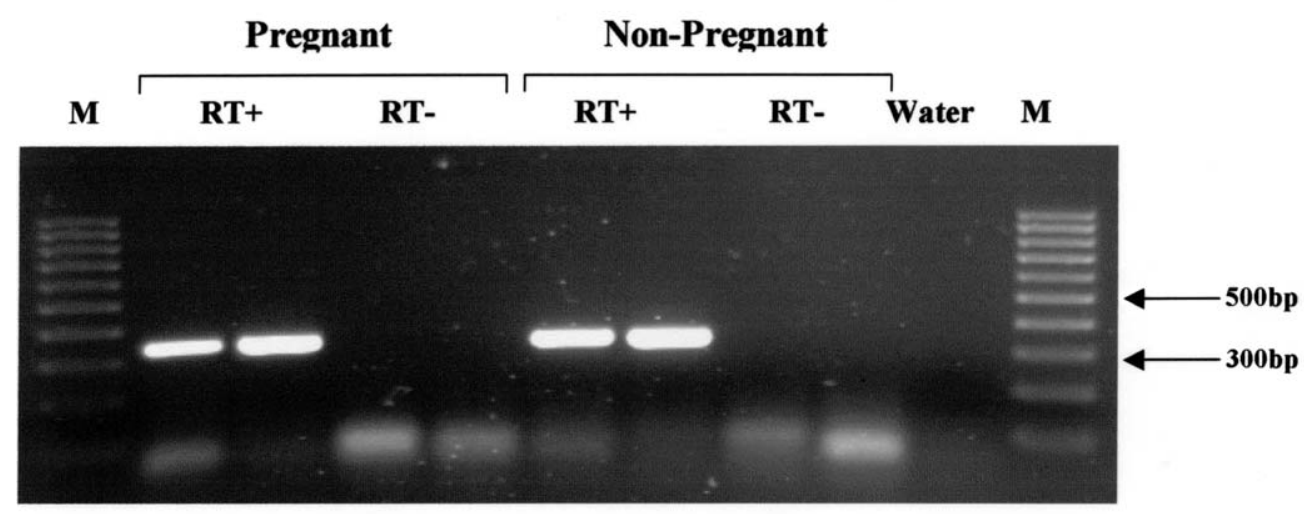

B

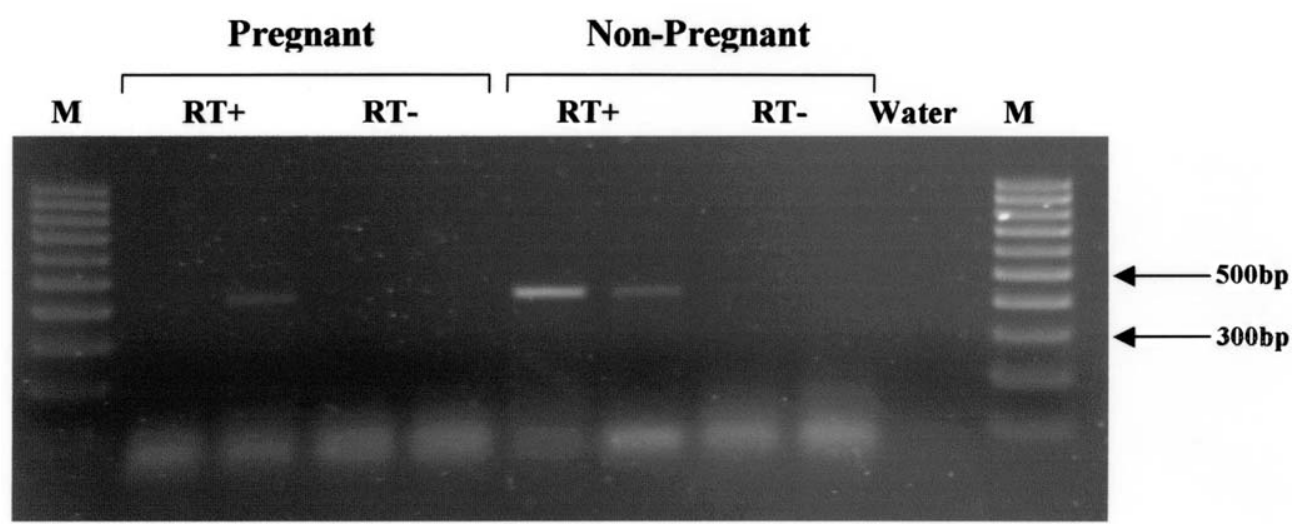

Figure 4 Representative agarose gel that was stained with ethidium bromide demonstrates the expression of $\mathrm{CB}_{1}$ mRNA $(\mathrm{A})$ and $\mathrm{CB}_{2}$ mRNA (B) in human pregnant $(\mathrm{n}=2$ specimens) and nonpregnant $(\mathrm{n}=2$ specimens) myometrium. Reverse transcriptase-negative $(R T-)$ controls for each candidate gene are shown alongside reverse transcriptase-positive $(R T+)$ PCR products. A water control is also included (no cDNA template). $M, 100$-bp marker.

channels and the activation of inwardly rectifying potassium channels, which would lead to membrane hyperpolarization and the inhibition of contractile activity. ${ }^{27}$ The mechanisms that are operative in human uterine tissue, which result in the degree and potency of relaxation observed in this study, remain a topic for future research. Little is known about the physiologic role of the $\mathrm{CB}_{2}$ receptors, but $\mathrm{CB}_{2}$ mRNA is present mainly in immune cells with particularly high levels in B cells and natural killer cells, ${ }^{29}$ which suggests an immunomodulatory role. Although we have demonstrated $\mathrm{CB}_{2}$ mRNA in human myometrium during pregnancy, the $\mathrm{CB}_{2}$ receptor did not appear to have a major role in the relaxant effect that is elicited by cannabinoids.

Approximately $5 \%$ of women admit to using cannabis during pregnancy, ${ }^{2,30}$ but it is believed that this figure underestimates the true prevalence of cannabis smoking

\begin{tabular}{llc}
\multicolumn{2}{l}{ Table II } & Primers used for reverse transcription-PCR \\
\hline Gene & Sense $5^{\prime}-3^{\prime}$ & Antisense $5^{\prime}-3^{\prime}$ \\
\hline CB $_{1}$ receptor & GGTCCTCTCAGCACT- & TCCACTCCGTAGAGCATA- \\
& AGTCTCCT & GATGA \\
CB $_{2}$ receptor & CAGACATTTTCCCACACA- & CAAACACCGTCTTAATGA- \\
& TTGAT & GCTTG \\
\hline
\end{tabular}

at this time. According to previously measured serum concentrations of $\Delta^{9}$-THC in the serum of patients after the intake of marijuana, we have estimated that the serum levels would be in the micromolar range, which lies in the middle of our dose response curve. ${ }^{31,32}$ Our findings therefore suggest that smoking cannabis during pregnancy would exert a significant uterorelaxant effect. The link between cannabis use during pregnancy and the risk of 
preterm delivery has been the focus of much research, with conflicting reports from different studies. ${ }^{2,33,34}$ From a physiologic point of view, our results support the theory that cannabis use in itself, after standardization for other socioeconomic variables, should not be an independent risk factor for preterm delivery. The possibility that regular use after term might delay the onset of labor and therefore increase stillbirth rates, as shown in animal studies, ${ }^{14}$ is raised however by our findings.

The studies that are mentioned here can only be performed in vitro in human uterine tissue for obvious ethical reasons. There are some limitations in extrapolation from in vitro studies to the in vivo situation. Our findings do not account for a possible central effect of endogenous and exogenous cannabinoids that, it appears, may have further relaxant effects on peripheral smooth muscle tissues. ${ }^{35}$ The possibility that cannabinoid effects on human uterine tissue may be altered during pregnancy, in comparison with nonpregnant myometrium, requires further evaluation. Finally, our study has focused on the effects on uterine smooth muscle and has not addressed the effects of cannabinoids on the fetus or the fetoplacental circulation.

In conclusion, endogenous and exogenous cannabinoids exert a potent relaxant effect in vitro on human uterine smooth muscle during pregnancy. This direct effect is mediated through the $\mathrm{CB}_{1}$ receptor. This highlights the possibility of a physiologic role for endogenous cannabinoids during human pregnancy and parturition. Our results support the view that exogenous cannabis use during pregnancy is not linked independently to preterm delivery.

\section{References}

1. Hall W, Solowij N, Lemon N. The health and psychological consequences of cannabis use: series No. 25. Canberra (Australia): Australian Government Publishing Service; 1994.

2. Fergusson DM, Horwood LJ, Northstone K, ALSPAC Study Team. Maternal use of cannabis and pregnancy outcome. BJOG 2002;109:21-7.

3. Sherwood RA, Keating J, Kavvadia V, Greenough A, Peters TJ. Substance misuse in early pregnancy and relationship to fetal outcome. Eur J Pediatr 1999;158:488-92.

4. Hatch EE, Bracken MB. Effect of marijuana use in pregnancy on fetal growth. Am J Epidemiol 1986;124:986-93.

5. Cornelius MD, Taylor PM, Geva D, Day NL. Prenatal tobacco and marijuana use among adolescents: effects on offspring gestational age, growth and morphology. Pediatrics 1995;95: 738-43.

6. Fried PA, James DA, Wilkinson B. Growth and pubertal milestones during adolescence in offspring prenatally exposed to cigarettes and marijuana. Neurotox Teratol 2001;23:431-6.

7. Hingson R, Alpert JJ, Day N, Dooling E, Kayne H, Morelock S. Effects of maternal drinking and marijuana use on fetal growth and development. Pediatrics 1995;95:738-43.

8. Matsuda LA, Lolait SJ, Brownstein MJ, Toung AC, Bonner TI. Structure of a cannabinoid receptor and functional expression of the cloned cDNA. Nature 1990;346:561-4.
9. Munro S, Thomas KL, Abu Shaar M. Molecular characterization of a peripheral receptor for cannabinoids. Nature 1993;365:61-5.

10. Devane WA, Hanus L, Breuer A, Pertwee RG, Stevenson LA, Griffin $\mathrm{G}$, et al. Isolation and structure of a brain constituent that binds to the cannabinoid receptor. Science 1992;258:1946-9.

11. Hillard CJ. Endocannabinoids and vascular function. J Pharmacol Exp Ther 2000;294:27-32.

12. Pertwee RG. Cannabinoids and the gastrointestinal tract. Gut 2001;48:859-67.

13. Wilson RI, Nicoll RA. Endocannabinoid signaling in the brain. Science 2002;296:678-82.

14. Wenger T, Fragkakis G, Giannikou P, Probonas K, Yiannikakis $\mathrm{N}$. Effects of anandamide on gestation in pregnant rats. Life Sci 1997;60:2361-71

15. Wenger T, Toth BE, Juaneda C, Leonardelli J, Tramu G. The effects of cannabinoids on the regulation of reproduction. Life Sci 1999;65:695-701.

16. Pertwee RG. Pharmacology of cannabinoid CB1 and CB2 receptors. Pharmacol Ther 1997;74:129-80.

17. Howlett AC, Mukhopadhyay S. Cellular signal transduction by anandamide and 2-arachidonoylglycerol. Chem Phys Lipids 2000; 108:53-70.

18. Mu J, Zhuang SY, Kirby MT, Hampson RE, Deadwyler SA. Cannabinoid receptors differentially modulate potassium A and D currents in hippocampal neurons in culture. J Pharmacol Exp Ther 1999;291:893-902.

19. Dennedy MC, Houlihan DD, McMillan H, Morrison JJ. $\boldsymbol{\beta}_{2^{-}}$and $\boldsymbol{\beta}_{3}$-adrenoreceptor agonists: human myometrial selectivity and effects on umbilical artery resistance. Am J Obstet Gynecol 2002; 187:641-7.

20. Houlihan DD, Dennedy MC, Morrison JJ. Polyamine effects on human myometrial contractility. Am J Obstet Gynecol 2002;186: 778-83.

21. Moran CJ, Friel AM, Smith TJ, Cairns M, Morrison JJ. Expression and modulation of Rho kinase in human pregnant myometrium. Mol Hum Reprod 2002;8:196-200.

22. Coutts AA, Brewster N, Ingram T, Razdan RK, Pertwee RG. Comparison of novel cannabinoid partial agonists and SR141716A in the guinea-pig small intestine. $\mathrm{Br} \mathrm{J}$ Pharmacol 2000;129:645-52.

23. Portier M, Rinaldi-Carmona M, Pecceu F, Combes T, PoinotChazel C, Calandra B, et al. SR 144528, an antagonist for the peripheral cannabinoid receptor that behaves as an inverse agonist. J Pharmacol Exp Ther 1999;288:582-9.

24. Chromcyznski P. A reagent for the single-step simultaneous isolation of RNA, DNA and proteins from cell and tissue samples. Biotechniques 1993;15:532-4, 536-7.

25. Schmid PC, Paria BC, Krebsbach RJ, Schmid HH, Dey SK. Changes in anandamide levels in mouse uterus are associated with uterine receptivity for embryo implantation. Proc Natl Acad Sci U S A 1997;94:4188-92.

26. Maccarrone M, Bisogno T, Valensise H, Lazzarin N, Fezza F, Manna C, et al. Low fatty acid amide hydrolase and high anandamide levels are associated with failure to achieve an ongoing pregnancy after IVF and embryo transfer. Mol Hum Reprod 2002;8:188-95.

27. Izzo AA, Masscolo N, Capasso F. The gastrointestinal pharmacology of cannabinoids. Curr Opin Pharmacol 2001;1:597-603.

28. Zygmunt PM, Hogestatt ED, Waldeck K, Edwards G, Kirkup AJ, Weston AH. Studies on the effects of anandamide on rat hepatic artery. Br J Pharmacol 1997;122:1679-86.

29. Galiegue S, Mary S, Marchand J, Dussossoy D, Carriere D, Carayon $\mathrm{P}$, et al. Expression of central and peripheral cannabinoid receptors in human immune tissues and leukocyte subpopulations. Eur J Biochem 1995;232:54-61.

30. Vaughn AJ, Carzoli RP, Sanchez-Ramos L, Murphy S, Khan N, Chiu T. Community wide estimation of illicit drug use in delivering 
women: prevalence, demographics and associated risk factors. Obstet Gynecol 1993;82:92-6.

31. Perez-Reyes M, White WR, McDonald SA, Hicks RE, Jeffcoat AR, Cook CE. The pharmacologic effects of daily marijuana smoking in humans. Pharmacol Biochem Behav 1991;40:691-4.

32. Huestis MA, Sampson AH, Holicky BJ, Henningfield JE, Cone EJ. Characterisation of the absorption phase of marijuana smoking. Clin Pharmacol Ther 1992;52:31-41.
33. Gibson GT, Baghurst PA, Colley DP. Maternal alcohol, tobacco and cannabis consumption and the outcome of pregnancy. Aust $\mathrm{N}$ Z J Obstet Gynaecol 1983;23:15-9.

34. Linn S, Schoenbaum SC, Monson RR, Rosner R, Stubblefield PC, Ryan KJ. The association of marijuana use with outcome of pregnancy. Am J Public Health 1983;73:1161-4.

35. Ameri A. The effects of cannabinoids on the brain. Prog Neurobiol 1999;58:315-48.

\section{Bound volumes available to subscribers}

Bound volumes of the American Journal of Obstetrics and Gynecology are available to subscribers (only) for the 2004 issues from the publisher, at a cost of $\$ 122.00$ for domestic and \$146.00 for international for Vol. 190 (January-June) and Vol. 191 (July-December). Shipping charges are included. Each bound volume contains a subject and author index, and all advertising is removed. The binding is durable buckram with the Journal name, volume number, and year stamped in gold on the spine. Payment must accompany all orders. Contact Elsevier Inc, Subcription Customer Service, 6277 Sea Harbor Dr, Orlando, FL 32887. Telephone (800)654-2452 or (407)345-4000. Fax (407)363-9661.

Subscriptions must be in force to qualify. Bound volumes are not available in place of a regular Journal subscription. 